\title{
Studying the Effectiveness of the Internal Control System on the Corporate Value and Dividend in Listed Companies in Tehran Stock Exchange
}

\author{
Zainab Rezaie Gilandeh ${ }^{1,2}$, Nasrin Khodabakhshi*3, Abdullah Pakdel \\ Moghanloo ${ }^{1,2}$ \\ ${ }^{I}$ Department of Accounting, Ardabil Science and Research branch, Islamic Azad University, Ardabil, \\ Iran \\ ${ }^{2}$ Department of Accounting, Ardabil Branch, Islamic Azad University, Ardabil, Iran \\ ${ }^{3}$ Department of Accounting, Khalkhal branch, Islamic Azad University, Khalkhal, Iran,
}

\begin{abstract}
Quality of financial information to inside and outside users of the organization has a particular importance. Many factors affect the quality of the financial information that the internal control system of reporting unit is one the most important factorsManyexpertsbelieve that by identifying weak and improvement pointsofinternal control systemcan be achieved higher level of quality in the preparation and disclosure of financial information with a lower cost and raised the value of the company. Since the aim of this study is the effect of internal control system improving on the company's value and dividend in listed companies on Tehran stock exchange. In this research, 118 companies were studied by using systematic elimination during the period 2010 to 2014. The panel data regression method was used to analysis in this research. The results indicate that improvement of the internal control system has a direct impact on the value and dividend of the companies.

Keywords: internal control system, company's value, dividend, Tehran Stock Exchange
\end{abstract}

\section{Introduction}

Earning is one of the most important items that the users of financial statements use it to evaluate the performance and profitability of it. Investors also benefit from the information they use to predict the future. Also, invertors use earning information in order to predict future. In addition, they pay special attention to the quantity of earning, quality indices of earning also considered as one aspect of the earning information (Nikomaram and et al, 2010).Dividend is an important issue that has long attracted the attention of researchers in the field of finance and still it remains as one of the most controversial issues in the field of financial management. Identifying effective factors on the ratio of dividend has attracted manyresearchers' attention. The decision on the amount of payment of dividend is an important decision that the company is facing with it because dividend is an effective factors on the value of the company.

Dividend policy among the shareholders make possible the continuity activity of the company and maximize shareholders' wealth is possible in this way. In addition, dividend policy canimpact directly on the shareholders' expect, free cash flow, method of financing, financial structure and continuity of the profit unit (Fairchild et al., 2014).Valuation of companies is one of the most important and most complicated economic concepts in each country, so that in developed countries that have progressive capital market and systematic, the companies value determine by investment banks, investment advisors and standards and specific rules to each industry (Accounting Standards Committee, 2008). In Iran, due to the low efficiency of investment market and very limited activity of capital market that have recently been established and has not demonstrated any activity, valuation of firms is impractical and follows by trial and error. (Lipson and Sandra, 2009).

Increasing developand complexity of economic units, continuous progress of technological, increase turnover, lack of resources, increased competition and a variety of threaten risks ofobjectivesand the organization's policies, has led to the minds of management have tend to myriad issues and direct and individual control of these units became impossible. (Kim et al., 2015).For this reason, the necessity to establish effective internal control system has received serious attention as an integral component of efficient management system (Choi et al., 2013). Internal control system is a dynamic system that cover a variety of risks and deviations from policies and procedures (Muhammadpour et al., 2013). The strong internal control systems have a significant effect on the reliability of financial reports.

According to the mentioned, internal control system may be one of the preventing way to decrease earnings quality. Strong internal control can increase dividend and the value of the company. Therefore, the objective of this study is to evaluate the effect of the internal control system improvement on firm value and dividend.So the question arises that what is the effect of theimprovement of the internal control system on firm value and dividends of listed companies in Tehran Stock Exchange? In this paper, first the literature of 
Studyingthe Effectiveness of the Internal Control System on the Corporate Value and Dividend in..

theresearch will review. Then the research methodology will provide and following findings, results, limitations and recommendations of the research will expressed.

\section{Theoretical principle}

\section{Review of the literature}

The nature of the internal control system of dividend payment depend on which company to carry out the task use the independent representation services of dividend paymentsor do it itself. Of course, from the perspective of the internal control system usage of independent representative is strongly recommended. Because the likelihood of fraud or mistake in the distribution of dividends is reduced in related to that, improvement of the internal control system lead to improve the quality of the reports. In other words, the internal control system cause to improve the dividendsituation. The term of internal control system may improve the company's value for shareholders and others. The reasonforthat is the reduction of risk information or improvement of executive activities.If the value of the company became more after improvement of the internal controlsystem shows that domestic instruction forlistedpublishers on stock, provide good information for shareholders and other stakeholders that have been very useful for company (Jiao et al., 2011).

\section{Experimental background}

Hejazi and Ismailikia (2013) in their study, evaluated the effect of planning systems of organizational resource on the effectiveness of internal controls about financial reporting. The research findings showed that companies with enterprise resource planning systems less likely to have internal control weaknesses compare to enterprise without resource planning systems.

Also companies that were unprofitable, during the study period, have mergers and acquisitions activities and have less market value of settlement enterprise resource planning systems in the shorter they are, the less likely there are weaknesses in the internal control system and of lower than lack of experience.Mohammadpur and colleagues (2013), in an article assessed the internal control and disclosure of information works. The results of the research show that internal control report,is more likely to cause published enterprise reliability of information and considerablystrengthen the characteristics of the information. So we can conclude that internal control report from the perspective of all user groups enhance the quality of data reported, especially now after the reliability of information. Also reporting on internal controls, if so required by law, cause to improve financial reporting of the company.Rahimian and Tavakolnia (2012) in an article, examined the role of internal audit in internal quality control system. The results show that the internal audit unit management, internal auditors' professional competence and impartiality of the ability of the internal control system has a significant impact on the company background and affects the process of audit that is done by assessing the internal control system.

Hashemi and Akhlaghi (2011), in his study to investigate the relationship between the value of the company's future with capital structure and dividend policy and profitability of listed companies on Tehran's Stock Exchange. The results of the analysis of data by using panel data is confirmed both hypotheses.In other words, between capital structure and profitability, a significant positive correlation with firm value, and the dividend policy is a significant inverse relationship with the value of the company. Also a significant relationship was found between the variables studied and the future value of the company. In addition, the results showed that the risk increases with higher rates in the future value of the company's capital structure, dividend policy and increased profitability.Filcherd and colleagues (2014) examined the dividend paid in Thailand. The aim of their study was to examine changes in the distribution of dividends in emerging market in Thailand. Overall, they found that there is little support for the signaling hypothesis and a significant support to the free cash flow hypothesis and life cycle. Their analysis suggested that the increased power of capital investment over the ownership change will lead to higher dividend in conclusion model compared to foreclosures models.Scaife et al (2013) studied the effect of internal control over financial reporting and management decisions. Researches shows that internal control impact on financial reporting and its subsequent will impact on management decisions.Kim and Park (2011) found in his research, when the existence of weaknesses in its internal control system experiences, its creditors to impose a higher cost of financing.

Yazawa(2010) explores the factors influencing important weaknesses in internal controls, they found that companies with internal weaknesses are small and more complex companies and financially weaker and a slowdown growth and also found internal control weaknesses have an impact on stock prices and on the other hand they found that the companies may not identify major weaknesses.Ge. et al (2007) in their study, examine the relationship between AQ and internal controls in companies in which examined reported weaknesses in internal controls over financial reporting under rules 302 and 404 Sarbinz - Okslee's report. When there are important weaknesses in internal control, it is likely that prevent material misstatements or not diagnosed annually. They concluded that internal control weaknesses associated with a relatively low accruals quality and internal control material weaknesses in direct correlation with accruals (for example, profitability ) and also 
investigate that strong internal controls associated with earnings management. They concluded that problems of internal control is an origin for accruals with low quality.

\section{Research hypotheses}

According to the theoretical principle and previous researches, hypotheses of the study are as follows.

Hypothesis 1: The system of internal control significant effect on economic added value.

Hypothesis 2: internal control system has a significant impact on the market value.

Hypothesis 3: Internal control has significant impact onQ Tobin's system.

Hypothesis 4: The internal control system has a significant impact on earnings per share.

Hypothesis 5: internal control systems significant effect on profits arising from operational activities.

\section{Research methodology}

The study in term of aim is applied and in term of method is descriptive - analytical. In this study has been tried todoexperimental test between cash and investment reserves. Research by using a panel data has been done. EViews software is used to estimate the research models.

\section{Research models}

This study tests the hypothesis for the following models.

Model 1:EVA $A_{\text {it }}=\beta_{0}+\beta_{1} \mathrm{IC}_{\text {it }}+\beta_{2} \mathrm{SIZE}_{\text {it }}+\beta_{3} \mathrm{LEV}_{\mathrm{it}}+\beta_{4} \mathrm{GROw}_{\mathrm{it}}$

Model 2: MVA $_{\text {it }}=\beta_{0}+\beta_{1} \mathrm{IC}_{\text {it }}+\beta_{2} \mathrm{SIZE}_{\text {it }}+\beta_{3} \mathrm{LEV}_{\text {it }}+\beta_{4} \mathrm{GROw}_{\mathrm{it}}$

Model 3: $Q_{i t}=\beta_{0}+\beta_{1}$ IC $_{\text {it }}+\beta_{2}$ SIZE $_{\text {it }}+\beta_{3} \mathrm{LEV}_{\text {it }}+\beta_{4} \mathrm{GROw}_{\text {it }}$

Model4:DP it $=\beta_{0}+\beta_{1} \mathrm{IC}_{\text {it }}+\beta_{2} \mathrm{SIZE}_{\text {it }}+\beta_{3} \mathrm{LEV}_{\text {it }}+\beta_{4} \mathrm{GROw}_{\text {it }}$

Model 5: $\mathrm{DR}_{\text {it }}=\beta_{0}+\beta_{1} \mathrm{IC}_{\text {it }}+\beta_{2} \mathrm{SIZE}_{\mathrm{it}}+\beta_{3} \mathrm{LEV}_{\text {it }}+\beta_{4} \mathrm{GROw}_{\mathrm{it}}$

\section{The study variables}

The dependent variable

Company's value divided with three varying economic added value, market added value and Tobin's $\mathrm{Q}$.

$\mathrm{EVA}=(\mathrm{ROIC}-\mathrm{WACC}) \times \mathrm{IC}$

Economic value added

ROIC $=$ return on invested capital that obtained by dividing operating profit after tax on invested capital (IC).

IC $=$ invested capital amount that is equal to net property, machinery, equipment + other assets + intangible assets + (current assets - current liabilities excluding financial credits) - Long-term debt + interest-bearing financial liabilities + other liabilities + regulatory capital reserves + retained earnings + storage + staff redundancy

$\mathrm{WACC}=(\mathrm{Ve} * \mathrm{Ke})+(\mathrm{VS} * \mathrm{KS})+(\mathrm{Vd} * \mathrm{Kd})$

MVA $=$ Market Value Added

MVA = value of equity provided by the shareholders - the market value of equity

Or

MVA = price per share in market * number of available shares - total equity

Tobin's $Q$ is equal to the sum of the market value of equity to book value of debt divided by the book value of assets

Dividend variable is measured by two variables DP and DR.

DP equals to ratio of dividends to earnings per share

DR equals to the ratio of dividends to profit from operating activities

\section{Independent variable}

IC: internal control system is measured by improving the control system $i$ in yeart. The independent variable through independent audit reports to the following readout considers that if the internal control is improved in year $t$ compared to the year $\mathrm{t}-1$ and equals to 1 , and otherwise is zero $(\mathrm{Wu}, 2011)$

\section{Controlvariables}

SIZE: the size of the company's market value is calculated based on the natural logarithm.

LEV: Financial leverage is equal to total debt divided on total assets.

GROW: company's growth that is equal to the natural logarithm of book value on market value.

\section{Statistical Population and sample}


The statistical population of this research is the company listed on the Tehran Stock Exchange. In this study, a special relationship to estimate sample size and sampling have been used, but all companies that are members of the population who have the following conditions, have been selected as member companies:

1. In 2009 or earlier they are accepted in Tehran Stock Exchange.

2. Company had no change in fiscal year during the research period

3. The Company's fiscal year during the entire period of the study,ended on March 29

4. The financial year will be 2010 to 2014 of the research period.

5. All variables are available in all of the examined years.

By above restrictions, 118 companies were selected as sample.

\section{Research findings}

In this study to test the stability of the test, Levin- Lin-Chu test was used. Given the significant level obtained for Levin- Lin-Chu test for all variables is less than 0.05 , we can conclude that the variables are stable, thus, according to the stability of variables in regression analysis, there is a problem of spurious regression (Table 1). To review the integration, statistic test, the null hypothesis that the lack of integration of the variables long-term relationship between the variables of the model refused to acknowledge (a significance level of less than 0.05 is obtained in Table 1).

Table1: Test stability and accumulation variables of the research

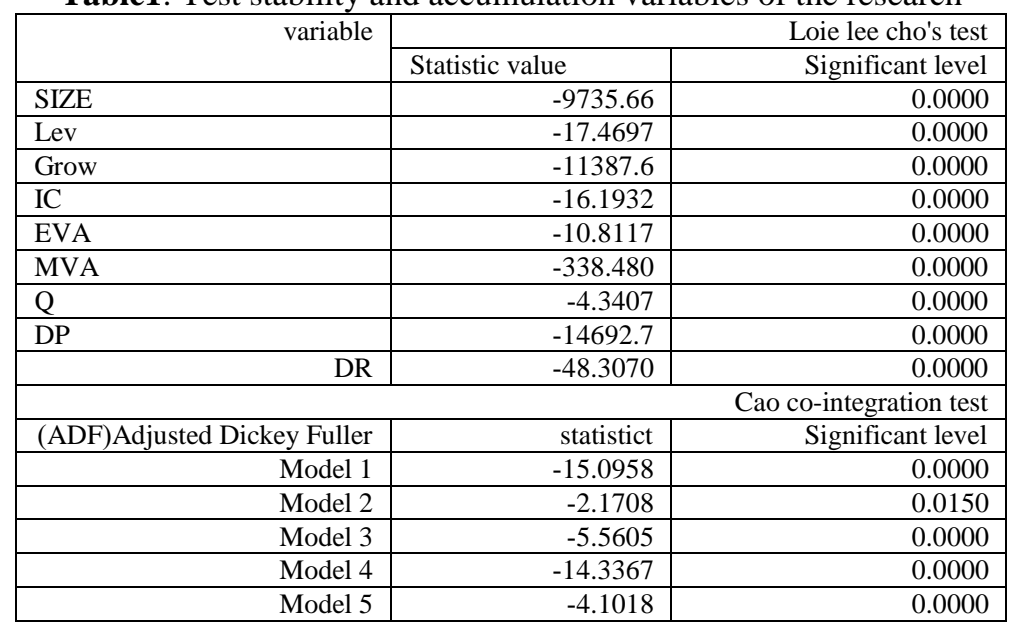

\section{Estimation Model}

\section{Limer'sF test}

At first was studied the appropriateness of fixed and random effects by using Limer's F test and Hausman.F Limer and Hausman test results are shown in Table 2. Because the significance of Limer'sFtestfor models 1 to 4 is less than 0.05 , so the null hypothesis of the test is rejected in favor of the alternative hypothesis so this test shows that the panel model is suitable for model 1 to 4 . The significance level is greater than 0.05 in model 5 also indicates that the hybrid modelis suitable for model 1 (Table 2).

Table 2: Test of F Limer

\begin{tabular}{|r|r|r|r|}
\hline Model & Statistic F & Significant level & Test resul \\
\hline Model 1 & 11.8858 & 0.0000 & Rejecting the null hypothesis \\
\hline Model 2 3 & 5.5406 & 0.0000 & Rejecting the null hypothesis \\
\hline Model 4 & 9.7595 & 0.0000 & Rejecting the null hypothesis \\
\hline Model 5 & 0.9949 & 0.0000 & Rejecting the null hypothesis \\
\hline
\end{tabular}

\section{Husman'stest}

Results of Husman's test for the choice between fixed and random effects in models 1 to 4 presented in Table 3. Given the significant level of Husman's test for from 2 to 4 models is less than 0.05 , So the null hypothesis is rejected on the suitability of random effects in these models and to evaluate 2 to 4 panel method the regression model is used with fixed effects regression models with random effects (Table 3).

Table3: Hausman's test

\begin{tabular}{|r|r|r|r|}
\hline Model & Chi-square statistic & Significant level & Test result \\
\hline
\end{tabular}

\begin{tabular}{llr|l}
\hline DOI: $10.9790 / 5933-0704019298$ & www.iosrjournals.org & $95 \mid$ Page
\end{tabular}


Studyingthe Effectiveness of the Internal Control System on the Corporate Value and Dividend in..

\begin{tabular}{|r|r|r|l|}
\hline Model 1 & 1.0657 & 0.8997 & Confirming the null hypothesis \\
\hline Model 2 & 33.3008 & 0.0000 & Rejecting the null hypothesis \\
\hline Model 3 & 275.4685 & 0.0000 & Rejecting the null hypothesis \\
\hline Model 4 & 25.8117 & 0.0000 & Rejecting the null hypothesis \\
\hline
\end{tabular}

In order to trust the results of model 1 to 3 , it should be considered a regression assumptions. The main assumption of multivariate regression analysis of regression is significant. In Table 4 and F-statistic significant level of uncertainty related to test a linear relationship (regression tests of significance) is between the independent variable and the dependent variable. Given that the level of significance of the test for models 1,2 and 3 is less than the significance level of 0.05 , we can conclude that the linear relationship between independent and dependent variables in all 3 model is approved.

One of the other assumptions that considered in regression, is independence errors (the difference between the actual values and the values predicted by the regression equation) of each other. If the hypothesis is rejected independence errors and errors are correlated with each other, there is not a possibility of regression. In order to evaluate the independence of error of each other, Durbin-Watson test was used. If the Durbin-Watson statistic closeto 2 (from 1.5 to 2.5) lack of correlation between errors will be accepted. According to Table 4, Durbin-Watson statistic for all three models is the right amount. The results of model1 to 3are shown in Table 4.

Table 4: Estimation of model 1,2 and 3

\begin{tabular}{|c|c|c|c|c|c|c|}
\hline Method & \multicolumn{2}{|c|}{$\begin{array}{r}\text { Panel regressions (random } \\
\text { effects) }\end{array}$} & \multicolumn{2}{|c|}{$\begin{array}{lrr}\text { Regression panel } & \begin{array}{r}\text { (fixed } \\
\text { effects) }\end{array} \\
\end{array}$} & \multicolumn{2}{|c|}{ Panel regression (fixed effects) } \\
\hline Dependent variable & & EVA & & MVA & & $\mathrm{Q}$ \\
\hline variables & Coefficient & $\begin{array}{r}\text { significance } \\
\text { level }\end{array}$ & Coefficient & $\begin{array}{r}\text { significance } \\
\text { level }\end{array}$ & Coefficient & $\begin{array}{r}\text { significance } \\
\text { level }\end{array}$ \\
\hline IC & 44677.52 & 0.4627 & 11204978 & 0.0012 & 53016.75 & 0.0164 \\
\hline SIZE & -53301.56 & 0.5400 & 7466892 & 0.0473 & 145207.6 & 0.0000 \\
\hline LEV & 1340415 & 0.0000 & 1266405 & 0.9333 & -1101877 & 0.0000 \\
\hline GROW & -48252.57 & 0.0525 & 5273341 & 0.056 & 24718.68 & 0.0022 \\
\hline $\mathrm{C}$ & -303320.6 & 0.7875 & -89321579 & 0.0703 & -488697 & 0.0006 \\
\hline Statistic F & & 8.2088 & & 10.5137 & & 210.853 \\
\hline significance level & & 0.0000 & & 0.0000 & & 0.0000 \\
\hline $\begin{array}{r}\text { Determination } \\
\text { coefficient }\end{array}$ & & 0.05 & & 0.73 & & 1.98 \\
\hline $\begin{array}{r}\text { Durbin-Watson } \\
\text { statistic }\end{array}$ & & 1.62 & & 1.48 & & 1.65 \\
\hline
\end{tabular}

The estimated results are shown in Table 4 and 5. In order to trust model 4 and 5 , the results of the regression assumptions should be investigated. The underlying assumption of multivariate regression analysis of regression is significant. In Table 5, F-statistics and significant level of uncertainty related to test is a linear relationship (regression test the overall significance) is the independent variable and the dependent variable. Given that the level of significance of the test for models 4 and 5 of the persistent level is less than 0.05 , we can conclude that the linear relationship between the dependent and independent variables in the models 4 and 5 was approved. Another assumptions is that we consider regression, independence errors (the difference between the actual values and the predicted values by the regression equation) of each other.

If the hypothesis is rejected independence errors and errors are correlated with each other,there is not the possibility to use the regression. In order to evaluate the independence of error of each of the Durbin-Watson test is used. If the Durbin-Watson statistic closetonumber 2 (from 1.5to 2.5) non-correlation between errors will be accepted. According to table 5 Durbin-Watson statistic for models 4 and 5 is a suitable value.

Table 5: Estimated model 4 and 5

\begin{tabular}{|c|c|c|c|c|}
\hline Method & \multicolumn{2}{|c|}{ Panel regression (fixed effects) } & \multicolumn{2}{|r|}{ Pooled regression } \\
\hline Depend variable & & DP & & DR \\
\hline variables & Coefficient & Significant level & Coefficient & Significant level \\
\hline $\mathrm{IC}$ & 2.403072 & 0.0714 & 0.205708 & 0.0000 \\
\hline SIZE & -3.69894 & 0.0113 & 0.019191 & 0.329 \\
\hline LEV & 2.072342 & 0.7236 & -0.69517 & 0.0000 \\
\hline GROW & -7.11527 & 0.0000 & 0.013876 & 0.285 \\
\hline $\mathrm{C}$ & 49.15566 & 0.0103 & 0.849161 & 0.003 \\
\hline Statistic F & & 22.35 & & 16.178 \\
\hline $\begin{array}{l}0.0000 \\
\end{array}$ & & 0.0000 & & 0.0000 \\
\hline Determination coefficient & & 0.85 & & 0.10 \\
\hline Durbin-Watson statistic & & 1.72 & & 1.71 \\
\hline
\end{tabular}

Hypothesis 1: The system of internal control has significant effect on economic value added. 
According to the results of the analysis of the data was the result of the variable rate control system is equal to 44677.52. The significance level obtained coefficient is equal to 0.4627 . Given that a significant level obtained internal control system for variable coefficients higher than $0.01,0.05$ and 0.1 . We conclude that the internal control system does not have a significant impact on economic value added. So we can conclude that hypothesis 1 that "the internal control system has a significant impact on economic value added." Is not approved (Table 4).Previous studies have shown that improving the weaknesses in the internal control system can increase the value of the company.Methods of control (control activities) the policies and procedures and the cases in addition to the items that are included in the control environment. These policies help to be able to deal with risk and provide long-term goals of the business unit took the necessary measures. In any business units, there is a lot of potential method to control (Agnova et al., 2007). So we can say that the results of this study does not match with the investigation Agnova et al (2007).

\section{Hypothesis 2: internal control system has a significant impact on the market value.}

According to the results of data analysis concluded that the internal control system variable coefficient is equal to 11204978. The significance level obtained coefficient is equal to 0.0012. Given that a significant level obtained internal control system for variable coefficient is less than 0.05. It concluded that the internal control system has a significant impact on the market value added. In other words we can say that the weakness (or improve) the internal control system, the company's market value also decreases (or increases). So we can conclude that sub-hypothesis 2 "internal control system has a significant impact on the market value." is approved by 95 percent of confidence (Table 4 ).

\section{Hypothesis 3: internal control system has significant effect on Q Tobin's}

According to the results of data analysis concluded that the internal control system variable coefficient is equal to 53016.75. Also, the obtained significance level of coefficient is equal to 0.0164. According to that a significant level obtained internal control system for variable coefficient is less than 0.05 , it follows that the internal control system has a significant impact on the Tobin Q. In other words, we can say that with improving the company's internal control system Tobin's Q is also increased. So we can conclude that hypothesis 3, the "system of internal control over Tobin's Q has a significant impact." is approved by 95 percent of confident (Table 4).

\section{Hypothesis 4: The internal control system has a significant impact on earnings of per share.}

According to the results of data analysis concluded that the internal control system variable coefficient is equal to 2.403072. The significance level obtained coefficient is equal to 0.0714 . According to that a significant level obtained internal control system for variable coefficient is lower than 0.1 error. It follows that internal control systems and a significant positive impact on the earnings per share. In other words, the improvement of the internal control system is also increasing earnings per share. So we can conclude that hypothesis 4, the "system of internal control significant effect on earnings per share is approval by 90 percent of confidence (Table 5).

\section{Hypothesis 5: internal control systems significant effect on profits arising from operational activities.}

According to the results of data analysis concluded that the internal control system variable coefficient is equal to 0.205708 . According to the obtained significance coefficient level equal to 0.05 . In other words, the improvement of the internal control system of operational activities increases, it can be concluded that internal control systems and a significant positive impact on profits resulting from operating activities. So we can conclude that hypothesis 5 that "the internal control system of operational activities significant effect on profits", is approved by 95 percent of confidence (Table 5).

\section{Conclusion}

From the past, accounting earning is a valuable digit of the financial earnings as a measure to evaluate performance and adopting rational decisions of interest to users of financial statements. One important issue in accounting research is the investigating the effect of the internal control system on value and dividend.The main objective of this study was to evaluate the effect of improving the internal control system on firm value and profit-sharing in companies listed in Tehran Stock Exchange during the 5-year period based on the analysis and testing hypotheses can be deduced that in the general case managers utilizing the company's system of internal control weaknesses discovered and try to improve it for next year.This issue cause thatthe company's performance improved dramatically. The results of this study indicate that the improvement of the internal control system has a direct impact on company value and dividend, match with the resultsofMohammadpur and colleagues(2013) and Scaife et al research (2013). 


\section{Research limitations}

Generally, there are a number of limitations in the way of any research about some of the limitations of this study, therefore can be said about some limitation:

1. Access to corporate data and spend a long time was associated with many problems. Stock Exchange database is not comprehensive and coherent reports is not held for financial companies (especially information prior years). Available software on the market (like Dena share, Tadbirpardaz) do not cover all the information, so this restriction eliminates a number of companies from samples.

2. Considering that the population of this study, companies in the Tehran Stock Exchange, the generalizability of the results to unlisted companies will be faced with restrictions. The restrictions on companies that participated in the exchange, but were removed from the study as well.

3. Since this study was conducted during the period from 2010 to 2014 , so proceedwithcaution in generalizing the results to other years.

\section{The research recommendation}

\section{Recommendations parallel to the hypotheses of test results}

1. On the results of hypothesis 2 and 3 that the significant effect of the internal control system on the market value and Tobin's Q was approved, it is suggested that managers implement and improve its internal control system to improve their added value and market value of the company to investors who seek to invest in companies that have a better performance, these companies have chosen to invest.

2. Based on the results of hypothesis 4 and 5 where a significant and positive impact on earnings per share system of internal control and profit from operating activities was approved, it is recommended that managers implement and improve its internal control system to improve their company's profitability criteria. To investors who seek to invest in companies that have a greater dividend, the company chose to invest.

\section{Recommendation to researchers for future research}

1. Studying the effect of improving the efficiency of the Company's internal control system

2. Studying the relationship between improving internal control system to corporate tax avoidance

3. Studying the mechanisms of corporate governance and improve internal control system

4. Using data mining techniques (artificial intelligence) to study the impact of the dividend and the Company's internal control system

\section{References}

[1]. Hejazi, Rezvan, Ismaili Kia, Gharibe (2013), the impact of enterprise resource planning systems on the effectiveness of internal controls over financial reporting, accounting empirical research, Issue 10

[2]. Rahimian, Nizamuddin, Tavakolnia, Ismael. (2012). the role of internal audit in the quality of internal audit.Auditor magazine. No. 59, pp. 104-113.

[3]. The Committee of audit standards, principles and standards of accounting and auditing. Auditing standards.Tenth Edition.2009.

[4]. Mohammadpour, Farshad; Tavakolnia, Ismail; Akbarpoor, Mojtaba. (2013). Assessment of internal control and disclosure of information works. The first monthly capital market of Iran. No. 107, pp. 62-67.

[5]. Nikomaram, Hashem. (2010). "The use of quality characteristics) theoretical concepts in assessing the quality of financial reporting profits", Journal of Management Studies, Issue 85, pp. 41-21.

[6]. HashemiseyeedAbbas and AkhlaghiHassanali(2011), Future Value of company's capitalstructure, dividend policy and the profitability of listed companies in Tehran Stock Exchange, Empirical Research in Accounting, Volume 1, Issue 2.

[7]. Fairchild, R., Guney, Y., Thanatawee, Y., (2014)., "Corporate Dividend Policy in Thailand: Theory and Evidence", Journal of Financial Economics 3, 360-305

[8]. Song-Hag Choi, Joonil Lee, Catherine HeyjungSonu. (2013). Determinants of human resource investment in internal controls China Journal of Accounting Research 6,pp167-185.

[9]. Marc 1.Lipson, Sandra Mortal, (2009), "Liquidity and capital structure ,Journal of Financial Markets 12, pages: 644-611

[10]. Seunghyun Kim a, Yoon Koh b, Jaemin Cha a, Seoki Lee.(2015). Effects of social media on firm value for U.S. restaurant companies. International Journal of Hospitality Management 49,pp40-46.

[11]. Yazawa, Kenichi ,(2010), Why Don't Japanese Companies Disclose Internal Control Weakness? : Evidence from J-SOX Mandated Audits. Aoyama Gakuin University, NO 32, PP.2-11.

[12]. JiaWu,linxiao Liu and Frederrick Jones,(2011),'Firm value and earnings management after internal control weakness remediation", internal journal of business research ,Volume11,Number5

[13]. Hollis A.Skaife, DavidVeenman, DanielWangerin. (2013). Internal control over financial reporting and managerial rent extraction: Evidence from the profitability of insider trading. Journal of AccountingandEconomics55, pp110-91 